\title{
Scientific and methodological foundations to develop numerical hydrodynamical models of mine fields in Donbas
}

\author{
Alina Zahrytsenko ${ }^{1 *}$, Olena Podvigina ${ }^{1}$, and Nataliia Dereviahina ${ }^{1}$ \\ ${ }^{1}$ National Mining University, Department of Hydrogeology and Engeenering Geology, \\ 19 Yavornytskoho Ave., 49005 Dnipro, Ukraine
}

\begin{abstract}
The paper considers specific character of hydrogeological problems arising during the whole cycle of a mining enterprise operation; the most reliable their solutions are implemented in the context of numerical hydrodynamical models of mine fields. Basic approaches to schematize laminated carbonic formation through simplification of natural rock mass permeability have been substantiated; prediction algorithm of its changes during temporal transformation has been developed. Numerous identification problems solving in the process of modeling mine fields has helped understand that water inflow amount cannot be correlated with the extension of mining area. Within the areas with roof caving, permeability of carbonic formation is a time variable which value increases $10-15$ times in the context of rock displacement, halves after $5-10$ years and nears natural values after $15-20$ years. In the context of Western Donbas, the modularized schemes have been tested while solving problems concerning filtration control within mine fields and their surface influence areas with high confidence of hydrogeological forecasts.
\end{abstract}

\section{Introduction}

Formation of technogenic mode of ground water within areas of underground mining influence is one of the most complicated processes among the whole system of anthropogenic effects on the underground hydrosphere as for predictability and controllability. In this connection, it is practical to use numerical geofiltrational modeling to evaluate hydrodynamical situation within mine fields. The evaluation is supported by the development of powerful computer facilities and corresponding software (Modflow, FEFLOW, HydroGeoSphere, MODHMS and others). Recent research by foreign authors $[1,2]$ are intended to study the processes of contaminant migration within geotechnical systems, modeling of saturated and unsaturated flows, and transportation of differentdensity solutions and heat.

However, modeling nature of such a complicated and multifactor geotechnical object as a mine originates a number of debating points at each stage of its functioning. The points are connected with the methodology of adequate simulation with the help of a model of

\footnotetext{
* Corresponding author: alinanik@bigmir.net
} 
geomechanically disturbed rock mass under different standard conditions of coal mines.

Mironenko V.A., Shestakov V.M., Zhernov I.E., Gavich I.K., Lomakin E.A. and others contributed much to the development of both theory and methodology of numerical modeling for mining hydrogeology. Recent studies of scientific team under the guidance of Norvatov Yu.A. concern geofiltrational studies in the process of operation and liquidation of mining enterprises. Paper [3] has developed typification of naturally technogenic structures on the basis of a character of hydraulic subsurface system-technogenic system connection; it involves rock mass disturbed by water-supply fissures; disintegrated rock within worked-out area; and unfilled stopes.

Several papers $[4,5]$ schematize naturally technogenic complex having a system of mine workings with up to $400 \mathrm{~m}$ thickness as a one-layer formation with indefinite temporal changes in the rock mass permeability parameters. Such simplification prevents from making a point of dynamics of inflow formation within certain seams and determining their factors generation. The hydrodynamic situation is described by means of parameters of pressure distribution in the context of final period of a mine operation; total cavitation volume of technogenic system is evaluated analytically on the ratio between a volume of all worked-out seams and a volume of technogenic complexes.

The authors agree as for the prevailing effect of compressibility of carbonic formation on the velocity of underground water level recovery in the context of flooding of mines; the fact is supported by research carried out for Central Donbas [6, 7] as well as for other regions of Ukraine [8,9]. Saturation velocity of disturbed rock mass is important while controlling a mine field flooding process; parameters of temporal permeability variations required to solve problems of water control in the process of a field development and to use the georesource during postdevelopment periods remain uncertain.

Thus, the studies are intended to substantiate scientific and methodological approaches to schematize natural hydrodynamical conditions of mine fields used to simulate technological process of coal seams mining and hydromechanical transformation of rock mass making it possible to determine factors of inflow formation and regularities concerning changes in temporal permeability of worked-out area.

The process involves a number of numerical experiments for the conditions of Western Donbas to develop a solution algorithm for identification problems to make decisions concerning filtration control within mine fields and areas of their surface effect.

\section{Results and discussion}

The model compliance with the study object and, hence, reliability of the obtained hydrogeological prognoses, depend upon the performance of schematization of hydrogeological conditions determined by formulation of practical tasks. The whole range of problems concerning water control in the context of coal-mining regions going with periods of mining, flooding, and postdevelopment, can be divided into two groups: mining and technological, and hydroecological (Fig. 1).

The above-mentioned peculiarities cannot cover the whole range of hydrogeological problems arising within mine fields differing in their hydrogeological conditions but being typical for the majority and making it possible to formulate general principles concerning the development of geofiltration schemes of mine fields. Simplification of environmental conditions as well as operative factors is performed in accordance with particular order; moreover, it consists of several stages (Fig. 2).

Many schematization techniques are well-known and have been published in the papers $[10,11]$. Turn our attention to the moments being important for the process of inverse problem solving and for the improvement of total reliability of modeling results. From the methodological viewpoint, substantiation of optimum number of simulation layers and modeling of laminated system of rocks are the most difficult problems. 


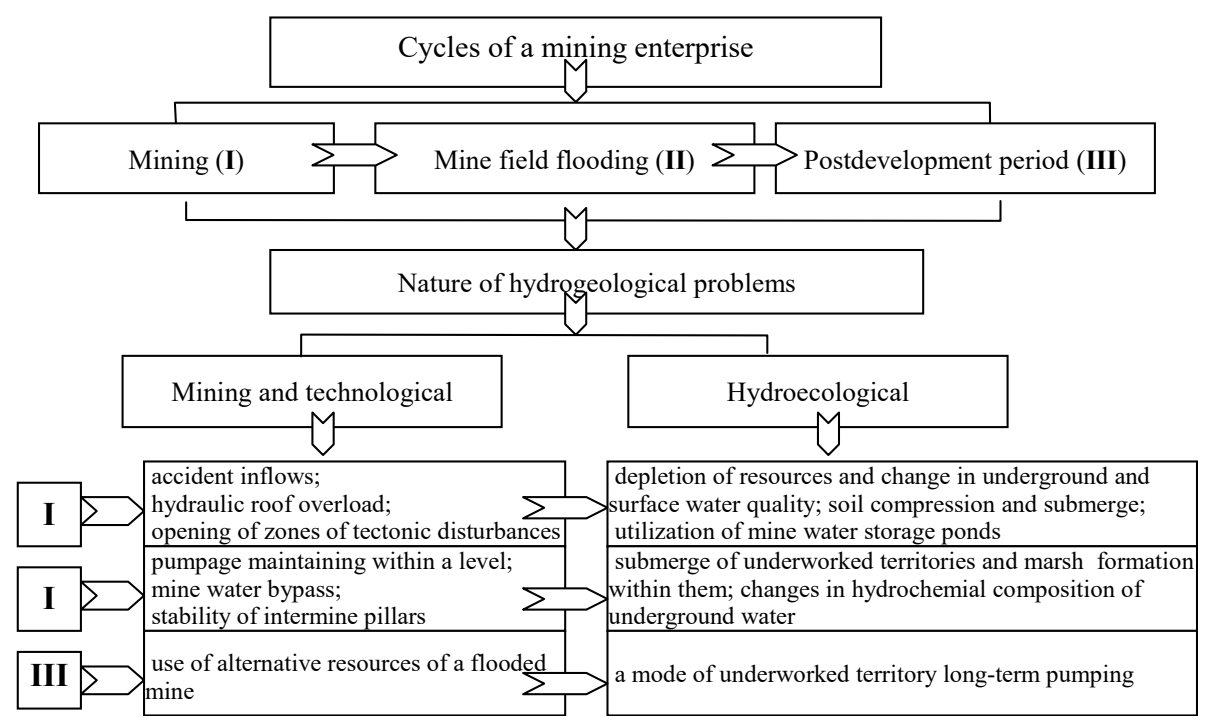

Fig. 1. Specific character of hydrogeological problems for a coal mine.

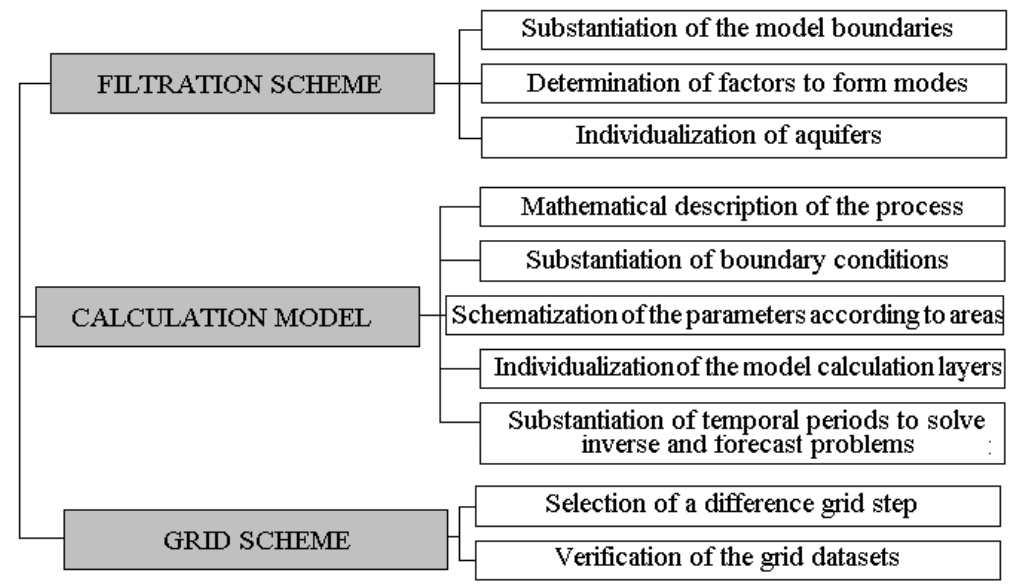

Fig. 2. Stages to develop geofiltrational scheme of a mine field model.

Layered water-bearing structure within the model is shown by means of weightaverage filtrational parameters in calculation blocks as well as dependency parameters in the context of calculation layers [12]. The number of calculation layers for each model is determined individually taking into consideration complexity of water-bearing structure, angle of rocks and fault planes of tectonic disturbances, and distance between levels of coal seams mining. To simulate actual hydrodynamic situation within mine fields of Western Donbas, carbonic formation with interbedding of argillites, aleurites, sandstones, limestones, and coal is schematized in the form of seams being extracted which thickness is determined by means of height of a zone of aquiferous fissures.

Most of all, parameters of sedimentary formation or a surface of water-bearing level, neighbouring a zone of intensive fissuring, are schematized with the help of hydraulic formulation basing upon a supposition by Miatiiev-Girinski (in the context of permeable layers, underground water moves horizontally; in the context of slightly permeable ones, the movement is vertical). Schematization of parameters of water-bearing formation of coal 
measures is implemented hydrodynamically. In this context, nonhomogeneous filtration area is divided into solid components by means of a system of mutually orthogonal planes in $X, Y$, and $Z$ coordinates.

A system of interbedding of well-permeable layers and slightly permeable ones is averaged out by means of weighted parameters along $X, Y$, and $Z$ axes. A level (pressure) within each simulation layer belongs to a centre of a solid component.

If rocks occur vertically (bedding angle is $\alpha=90^{\circ}$, Fig. 3) and the layer thickness is $h_{i}$, then the weighted values of filtration coefficient $k_{x}$ and $k_{y}$ are calculated according to the dependences corresponding to the filtration:

- in parallel with the bedding

$$
K_{y_{i}}=K_{z_{i}}=\frac{\sum k_{i} h_{i}}{\sum h_{i}}=\frac{\sum k_{i} h_{i}}{\Delta x}, K_{y_{i+1}}=K_{z_{i+1}}=\frac{\sum k_{i+1} h_{i+1}}{\sum h_{i}}=\frac{\sum k_{i+1} h_{i+1}}{\Delta x} ;
$$

- transversely to the bedding

$$
K_{x_{i}}=\frac{\sum h_{i}}{\sum \frac{h_{i}}{k_{i}}}=\frac{\Delta x}{\sum \frac{h_{i}}{k_{i}}}, K_{x_{i+1}}=\frac{\sum h_{i+1}}{\sum \frac{h_{i+1}}{k_{i+1}}}=\frac{\Delta x}{\sum \frac{h_{i+1}}{k_{i+1}}} .
$$

Filtration coefficient $K_{z_{i}, z_{i+1}}$ along $Z$ axis between blocks of neighbouring calculated layers is computed on the dependence according to filtration being transverse to $K_{z_{i}}$ and $K_{z_{i}+1}$ layers:

$$
K_{z_{i}, z_{i+1}}=\frac{\Delta z_{i}+\Delta z_{i+1}}{\frac{\Delta z_{i}}{K_{z_{i}}}+\frac{\Delta z_{i+1}}{K_{z_{i+1}}}}
$$

Relation parameter of neighbouring calculated layers (TR) along $Z$ axis is computed according to the formula:

$$
T R=\frac{\Delta z_{i}+\Delta z_{i+1}}{\frac{\Delta z_{i}}{K_{z_{i}}}+\frac{\Delta z_{i+1}}{K_{z_{i+1}}}} \times \frac{1}{0.5\left(\Delta z_{i}+\Delta z_{i+1}\right)} .
$$

Judging by the dependences, weighed values of filtration coefficients within blocks along $X$ and $Y$ axes will differ owing to the direction of underground water movement.

If layers occur horizontally (Fig. 4), then weighed values of filtration coefficients $k_{x}$ and $k_{y}$ within each layer (block) of the model are calculated on the dependence in parallel with bedding:

$$
K_{x_{i}}=K_{y_{i}}=\frac{\sum k_{i} h_{i}}{\sum h_{i}}=\frac{\sum k_{i} h_{i}}{\Delta z}, K_{x_{i+1}}=K_{y_{i+1}}=\frac{\sum k_{i+1} h_{i+1}}{\sum h_{i+1}}=\frac{\sum k_{i+1} h_{i+1}}{\Delta z_{i+1}} .
$$

Hence, along $Z$ axis, i.e. transversely to the bedding, $k_{z}$ is:

$$
K_{z_{i}, z_{i+1}}=\frac{\Delta z_{i}+\Delta z_{i+1}}{\left(\sum \frac{h_{i}}{k_{i}}+\sum \frac{h_{i+1}}{k_{i+1}}\right)}
$$




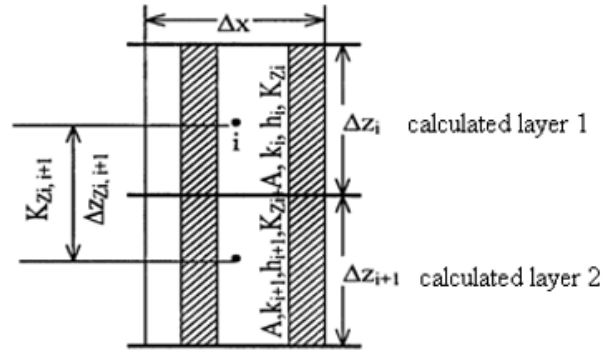

Fig. 3. Scheme of vertical arrangement of layers within the calculated blocks.

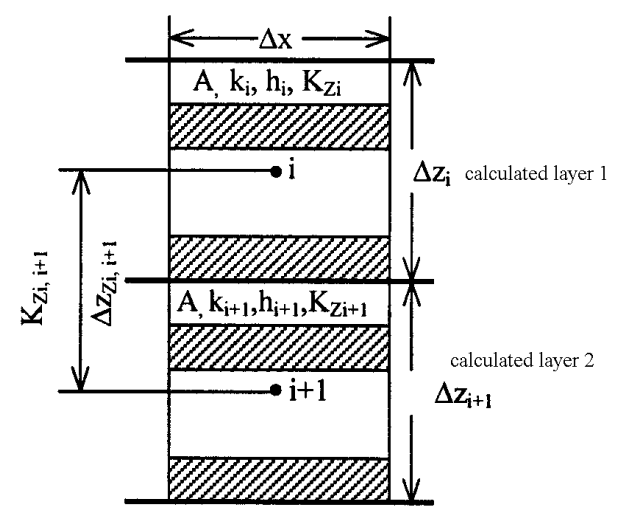

Fig. 4. Scheme of horizontal layer bedding within the calculated blocks.

Relation parameter of neighbouring calculated layers along $Z$ axis (TR) is computed according to dependence (4).

If layers occur aslope (Fig. 5), then average values of filtration coefficients $k_{x}$ and $k_{y}$ along $X$ and $Y$ axes for each block of the model are equal to:

$$
\begin{aligned}
& K_{x_{i}}^{\prime}=K_{x_{i}} \cdot \cos ^{2} \alpha+K_{z_{i}} \cdot \sin ^{2} \alpha ; \\
& K_{y_{i}}^{\prime}=K_{x_{i}} ; \\
& K_{z_{i}}^{\prime}=K_{x_{i}} \cdot \sin ^{2} \alpha+K_{z_{i}} \cdot \cos ^{2} \alpha .
\end{aligned}
$$

Filtration coefficient $K_{z_{i, i+1}}^{\prime}$ along $Z$ axis between blocks of the calculated layers is computed transversely to layers with perpendicular with $K_{z_{i}}^{\prime}$ and $K_{z_{i+1}}^{\prime}$ filtration coefficients:

$$
K_{z_{i, i+1}}^{\prime}=\frac{\Delta z_{i}+\Delta z_{i+1}}{\left(\frac{z_{i}}{K_{z_{i}}^{\prime}}+\frac{z_{i+1}}{K_{z_{i+1}}^{\prime}}\right)}
$$

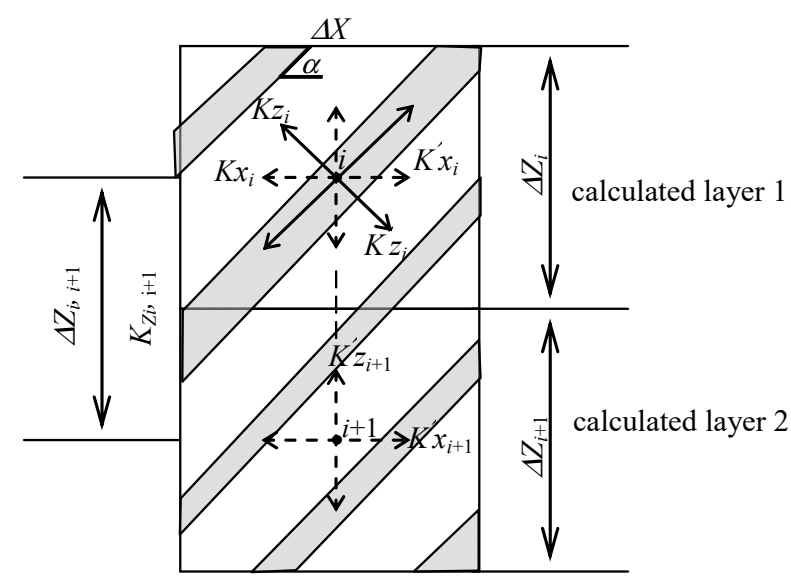

Fig. 5. Scheme of inclined bedding of layers within the calculated blocks. 
Array of anisotropy coefficient is introduced within the model to consider differences in filtration coefficients along $X$ and $Y$ axes. In this context, the anisotropy coefficient is a product of coefficients of natural anisotropy and that one obtained as a result of schematization of rock filtration properties.

It should be noted that natural carbon permeability increases in the process of a stope roof caving; it decreases when rocks compact. Thus, to reflect real processes taking place during mining, temporal changes have to be set within calculated blocks of the model: filtration coefficients of the calculated layers; underground water-mine workings relation parameters; neighbouring calculated layers - dewatering coefficients ratio. Meanwhile, in the process of technogenic transformation, their quantitative values are determined while solving inverse identification problems.

Simulation of long-term periodical chronology of coal seams mining [13] with typical water inflow dynamics is the feature of a mine field verification model. That makes it possible to determine water inflow formation factors in terms of each seam and evaluate quantitatively changes in permeability parameters of any worked-out rock mass in time.

Numerous identification problems solving in the process of modeling mine fields in the context of such mining enterprises as M.I. Stashkova mine, "Samarska", "ZakhidnoDonbaska", "Dniprovska" mines [14] has helped understand that water inflow amount cannot be correlated with the extension of mining area. Within the areas with roof caving, permeability of carbonic formation is a time variable which value increases $10-15$ times in the context of rock displacement, halves after $5-10$ years and nears natural values after $15-20$ years (Fig. 6).

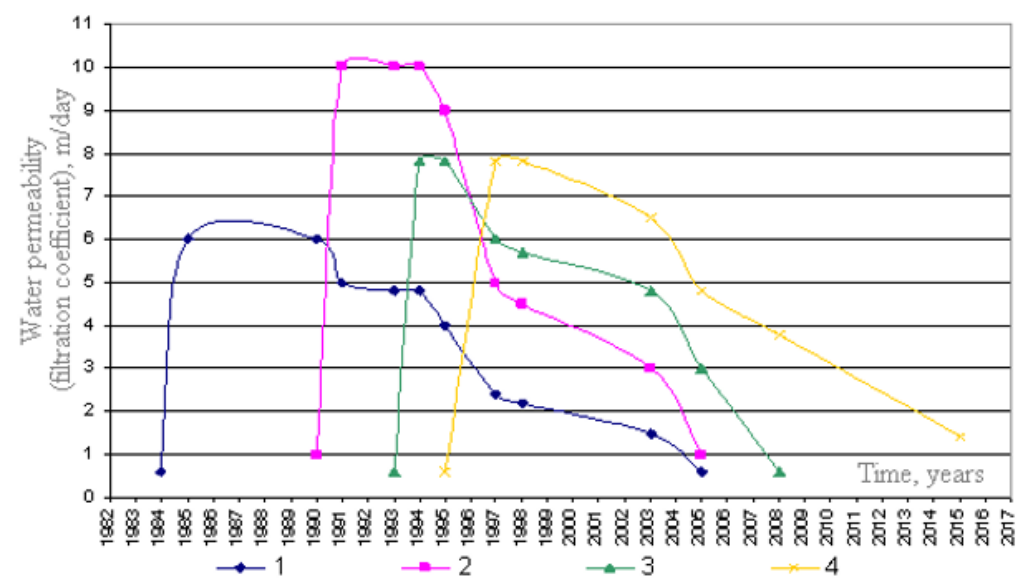

Fig. 6. Changes in water permeability in terms of $C_{5}$ seam within $(1-4)$ areas worked out during different time periods.

Identification of the models also has determined that permeability of high-amplitude tectonic faults (Bohdanovskyi and Prodolnyi) corresponds to the parameters of filtration shields (Table 1) where filtration coefficient is $10^{-4}-10^{-7} \mathrm{~m} /$ day.

Table 1. Hydrodynamical parameters of a zone of tectonic faults.

\begin{tabular}{|l|c|c|}
\hline \multicolumn{1}{|c|}{ Filtration and capacitive parameters } & A zone of tectonic faults & Behind fault area \\
\hline $\begin{array}{l}\text { Filtration coefficient, } \mathrm{m} / \text { day } \\
\left(C_{6} / C_{1} \text { seam }\right)\end{array}$ & $10^{-4} / 10^{-6}$ & $10^{-2} / 10^{-2}$ \\
\hline $\begin{array}{l}\text { Coefficient of elastic filtration } \\
\text { characteristic }\left(C_{6} / C_{1} \text { seam }\right)\end{array}$ & $10^{-6} / 10^{-7}$ & $10^{-5} / 10^{-5}$ \\
\hline
\end{tabular}




\section{Conclusions}

Factors to form water inflows as well as regularities concerning timely changes of the disturbed rock mass permeability have been determined at the stage of model identification on the dynamic similarity while simulating technological process to mine coal seams and to perform hydromechanical transformation of rock mass. That made it possible to develop adequate models of vine fields with prognostic decisions of high integrity (more than $90 \%$ ) as for the control of hydrodynamic situation both at the surface and underground, at the stage of intensive mining operations and at the final stage of liquidation and rock mass flooding.

The research has been carried out with financial support from "DTEK Pavlohradvuhillia" PJSC, Shahtoupravlinnia "Ternivske" and "Dniprovske. The authors are grateful for the Companies management and assistance in surveying and hydrogeomechanical monitoring in underground mine workings.

\section{References}

1. Barnett, B., Townley, L., Post, V., Evans, R., Hunt, R., Peeters, L., Richardson, S., Werner, A., Knapton, A., \& Boronkay, A. (2012). Australian groundwater modeling guidelines. Waterlines Report Series, June, (82), 204.

2. Shuchita Garg, S.K. (2016). Singh Modeling of arsenic transport in groundwater using MODFLOW: A case study. Inational journal of geomatics and geosciences, 6(4).

3. Norvatov, Yu.A., Petrova, I.B., \& Stepanova, A.S. (1999). Tipizatsiya usloviy obrazovaniya vodopritokov v gornykh vyrabotkakh pri nablyudenii za zatopleniem ugol'nykh shakht. Gornaya geomekhanika i marksheyderskoe delo, 117-121.

4. Norvatova, O.I. (2005). Metodika prognoza gidrogeologicheskikh usloviy dlya stroitel'stva ugol'nykh shakht na baze chislennogo modelirovaniya geofil'tratsionnykh protsessov (na primere Vostochnogo Donbassa). Phd. Vsesoyuznyy nauchno-issledovatel'skiy marksheyderskiy institut.

5. Savel'ev, D.I. (2014) Gidrogeologicheskoe obespechenie meropriyatiy po predotvrashcheniyu negativnykh posledstviy zatopleniya ugol'nykh shakht $\mathrm{Ph} . \mathrm{D}$. Natsionalnyy mineral'no-syr'yevoy universitet "Gornyy".

6. Sadovenko, I.A., \& Zagritsenko, A.N. (2003). Obosnovanie parametrov i sposobov upravleniya geofil'tratsionnym rezhimom ugleporodnogo massiva pri zatoplenii shakht. Sbornik nauchnykh trudov Natsionalnogo Gornogo Universiteta, 17(1), 48-51.

7. Sadovenko, I., Rudakov, D., \& Podvigina, O. (2010). Analysis of hydrogeodynamics in a mining region during exploitation till closure of coal mines. New Techniques and Technologies in Mining: School of Underground Mining, 61-69. https://doi.org/10.1201/b11329-12

8. Liashchova, M. (2016). Microfacies types and paleontological characteristics of the visean carbonate rocks (the southern zone of Dnieper-Donets basin). Visnyk of Taras Shevchenko National University of Kyiv. Geology, 2(73), 38-45. https://doi.org/10.17721/1728-2713.73.01

9. Pribilov, V. M. (2017). Assessment of technological pollution sources influence on underground water on the territory of Kharkiv region. Visnyk of V.N Karazin Kharkiv national university-series geology geography ecology, (47), 198-205. https://doi.org/10.26565/2410-7360-2017-47-26

10. Timoshchuk, V., \& Sherstyuk, Y. (2012). Geofiltration regularities in the areas loaded by gravitation in tailings and waste rock dumps. Naukovyi Visnyk Natsionalnoho Hirnychoho Universytetu, (4), 30-35.

11. Sadovenko, I., Zahrytsenko, A., Podvihina, O., \& Dereviahina, N. (2017). Water balance control within rock mass using the capacity of water-bearing formations. Naukovyi Visnyk Natsionalnoho Hirnychoho Universytetu, 4(160), 19-27.

12. Malashkevych, D., Sotskov V., Medyanyk V. \& Prykhodchenko D. (2018). Integrated Evaluation of the Worked-Out Area Partial Backfill Effect of Stress-Strain State of Coal-Bearing Rock Mass. Solid State Phenomena, (277), 213-220. https://doi.org/10.4028/www.scientific.net/ssp.277.213 
13. Fomichov, V., Sotskov, V., Pochepov, V. \& Mamaikin, O. (2018). Formation of a calculation model determining optimal rate of stping face movement with a large deformation of a rock massif. ARPN Journal of Engineering and Applied Sciences, 13(7), 2381-2389.

14. Sadovenko, I., Zahrytsenko, A., Podvigina, O., Dereviahina, N., \& Brzeźniak, S. (2018). Methodical and Applied Aspects of Hydrodynamic Modeling of Options of Mining Operation Curtailment. Solid State Phenomena, (277), 36-43. https://doi.org/10.4028/www.scientific.net/SSP.277.36 